\section{Backup Mechanism Maintains PACAP/VIP-Induced Arterial Relaxations in Pituitary Adenylate Cyclase-Activating Polypeptide-Deficient Mice}

\author{
Ivan Ivic ${ }^{a}$ b Balazs D. Fulop ${ }^{b}$ Tamas Juhasz $^{d}$ Dora Reglodi ${ }^{b}$ Gabor Toth $^{e}$ \\ Hitoshi Hashimoto ${ }^{g}$ Andrea Tamas ${ }^{b}$ Akos Koller ${ }^{c, f, h}$ \\ ${ }^{a}$ Institute for Translational Medicine and Departments of ${ }^{b}$ Anatomy and ${ }^{\circ}$ Neurosurgery, Medical School, \\ University of Pecs, Pecs, ${ }^{d}$ Department of Anatomy, Histology and Embryology, Faculty of Medicine, University of \\ Debrecen, Debrecen, ${ }^{e}$ Department of Medical Chemistry, University of Szeged, Szeged, and ${ }^{\mathrm{f} I n s t i t u t e}$ of Natural \\ Sciences, University of Physical Education, Budapest, Hungary; ${ }^{9}$ Laboratory of Molecular Neuropharmacology, \\ Graduate School of Pharmaceutical Sciences, United Graduate School of Child Development, The Datability Frontier \\ Institute, Osaka University, Osaka, Japan; h Department of Physiology, New York Medical College, Valhalla, NY, USA
}

(C) S. Karger AG, Basel

PROOF Copy
for personal
use only

ANY DISTRIBUTION OF THIS ARTICLE WITHOUT WRITTEN CONSENT FROM S. KARGER AG, BASEL IS A VIOLATION OF THE COPYRIGHT.

Please confirm that the authors' names and affiliations

have been identified correctly.

\section{Keywords}

Vasomotion - Carotid arteries · Femoral arteries · Pituitary adenylate cyclase-activating polypeptide $\cdot$ Vasoactive intestinal peptide - PACAP-KO mice - PAC1 receptor · VPAC1/NPAC2 receptors

\begin{abstract}
Background: Pituitary adenylate cyclase-activating polypeptide (PACAP) is a multifunctional neuropeptide in the $\mathrm{VIP} /$ secretin/glucagon peptide superfamily. Two active forms, PACAP1-38 and PACAP1-27, act through G proteincoupled receptors, the PAC 1 and VPAC $1 / 2$ receptors. Effects of PACAP include potent vasomotor activity. Vasomotor activity and organ-specific vasomotor effects of PACAP-deficient mice have not yet been investigated; thus, the assessment of its physiological importance in vasomotor functions is still missing. We hypothesized that backup mechanisms
\end{abstract}

\section{KARGER}

๑ 2017 S. Karger AG, Basel

E-Mail karger@karger.com www.karger.com/jvr exist to ensure the maintenance of PACAP activity in PACAP knockout (KO) mice. Thus, we investigated the vasomotor effects of vasoactive intestinal peptide (VIP) and PACAP isoforms in PACAP wild-type (WT) and PACAP-deficient (KO) male mice. Methods: Carotid and femoral arteries were isolated from 8- to 12-week-old WT and KO mice. Vasomotor responses were measured with isometric myography. $\boldsymbol{R e}$ sults: In the arteries of WT mice the peptides induced relaxations, which were significantly greater to PACAP1-38 than to PACAP1-27 and VIP. In KO mice, PACAP1-38 did not elicit relaxation, whereas PACAP1-27 and VIP elicited significantly greater relaxation in KO mice than in WT mice. The specific PAC1R and VPAC1R antagonist completely blocked the PACAP-induced relaxations. Conclusion: Our data suggest that in the absence of the PACAP beckup mechanisms maintain arterial relaxations, indicating an important physiological role for the PACAP pathway in the regulation of vascular tone.

(c) 2017 S. Karger AG, Basel

Dr. Akos Koller

Department of Physiology

New York Medical College

15 Dana Road, Valhalla, NY 10595 (USA)

E-Mail koller@nymc.edu 


\section{Introduction}

Pituitary adenylate cyclase-activating polypeptide (PACAP) is a neuropeptide with a diverse array of biological functions in many tissues and organs [1]. PACAP occurs in 2 biologically active forms, PACAP1-38 and PACAP1-27, with the former being the dominant form in mammalian tissues [1]. PACAP1-27 shares $68 \%$ identity with vasoactive intestinal peptide (VIP), which identifies PACAP as a member of the VIP-secretin-GHRHglucagon superfamily [2-4]. PACAP acts through G protein-coupled receptors, the specific $\mathrm{PACl}$ receptor (PAC1R), and the VPAC1/VPAC2 receptors (VPAC1R and VPAC2R). VPAC receptors also bind VIP and PACAP with similar affinity $[1,5-7]$. The PACAP isoforms and their receptors are widely expressed in the central nervous system $[8,9]$ and in peripheral organs, including blood vessels $[1,10]$. Numerous different functions have been described, such as the control of neurotransmitter release, activation of intestinal motility, influence on hormonal secretion, immune modulation, and stimulation of cell proliferation/differentiation/survival [1]. The widespread occurrence and the involvement in phylogenetically conserved processes suggest that this peptide exerts essential biological functions [11-13]. The PACAP polypeptides have multifaceted roles in the vascular system: their vasodilator activity and antioxidant properties have already been recognized [1]. In addition, PACAP exerts an important angiogenic capacity, as shown in cerebromicrovascular endothelial cells, which seems to decline with age [14], further underlying important physiological roles of PACAP signaling.

Although some data show that PACAP is able to exert a hypertensive action through the systemic release of catecholamines [15, 16], PACAP, similarly to VIP, is considered a potent vasorelaxant peptide $[17,18]$, causing a decrease in the mean arterial blood pressure $[17,19]$. The vasodilator activity of PACAP has been recorded in vessels of various organs in vitre in mice [20], rats [21-23], cats $[15,24]$, rabbits [25], dogs [21], pigs [18], and humans [26]. This action is mediated through all 3 PACAP receptors, which are highly expressed (alone/combined or all together) in the aorta [27], mesenteric [25], coronary [28], cranial arteries [10], pulmonary vascular bed [15], and many other blood vessels [1,29]. They are localized mainly in arteries and arterioles [25, 30].

The endogenous role of PACAP has been studied using PACAP-deficient mice (knockout; KO), It has been shown that PACAP-deficient mice have biochemical and metabolic abnormalities, behavioral alterations, and in- creased sensitivity to oxidative stress or in combination with other injuries (kidney and retinal ischemia, reduced immune response) resulting in a higher mortality rate [31]. The cardiovascular system is also altered in PACAPdeficient mice, as indicated by decreased cardiac function (measured with echocardiography), increased fibrosis, and myocardial degenerative changes (abnormal cardiomyocytes) [31, 32]. Markovics et al. [20] reported a reduced dilatator ability of meningeal arteries. However, it has not yet been demonstrated whether lack of PACAP leads to changes in vasomotor responses, so the assessment of its physiological importance is still missing.

Thus, in the present study we hypothesized that the vasomotor responses of isolated arteries will be altered in the absence of the PACAP protein in PACAP KO mice. Therefore, we aimed at investigating the relaxations of carotid (CA) and femoral (FA) arteries of PACAP wildtype (WT) and $\mathrm{KO}$ mice in response to cumulative doses of PACAP1-38, PACAP1-27, and VIP.

\section{Methods}

\section{Animals}

Experiments were performed on 8- to 12 -week-old male $\mathrm{KO}$ mice on a CD-1 background and their WT littermates [33]. A total of 45 animals were studied. At the time of the experiments, the average weight of WT mice was $36.89 \pm 0.76 \mathrm{~g}$ and that of KO mice was $35.45 \pm 0.43 \mathrm{~g}$ (the difference was not significant,$p<0.06$ ). Animal breeding, housing, and care, and the application of experimental procedures were conducted under approved protocols in accordance with ethical guidelines (University of Pecs; BA02/200015024/2011).

\section{Surgery}

The common CA and the proximal part of the FA were isolated using an Olympus surgical microscope (model SZX7; Olympus Inc., Tokyo, Japan) under anesthesia induced by the intraperitoneal injection of a ketamine (Gedeon Richter Plc., Budapest, Hungary) and xylazine (Eurovet Animal Health B.V., Bladel, The Netherlands) mixture (81.7 and $9.3 \mathrm{mg} / \mathrm{kg}$, respectively). The proximal and distal ends of the isolated segment were ligated, the vessel was excised between the ligations and then transferred to refrigerated Krebs solution. Both sides of the CA and FA arteries were used. After the removal of the arteries, the animal was euthanized with an intraperitoneal injection of pentobarbital $(100 \mathrm{mg} / \mathrm{kg}$; Ceva Sante Animale, Libourna, France).

\section{Pharmacological Agents}

The vasomotor function of vessels was studied in response to cumulative doses of PACAP1-38 and PACAP1-27 (from $10^{-9}$ to $10^{-6} \mathrm{M}$ ), which were synthesized as previously described [34], and VIP from $10^{-9}$ to $10^{-6} \mathrm{M}$ (Bachem, Bubendorf, Switzerland). Furthermore, selective agonists for PAC1R (maxadilan; Tocris Bioscience, Bristol, UK), VPAC1R (Ala ${ }^{11,22,28}$ VIP; Bachem), and VPAC2R (Bay55-9837; Bachem) receptors were also used from $10^{-10}$ 
Table 1. Nucleotide sequences, amplification sites, GenBank accession numbers, amplimer sizes, and PCR reaction conditions for each primer pair

\begin{tabular}{|c|c|c|c|c|c|}
\hline Gene & Primer & Nucleotide sequence $\left(5^{\prime} \rightarrow 3^{\prime}\right)$ & GenBank ID & $\begin{array}{l}\text { Annealing } \\
\text { temperature, }{ }^{\circ} \mathrm{C}\end{array}$ & $\begin{array}{l}\text { Amplimer } \\
\text { size, bp }\end{array}$ \\
\hline & antisense & GCT GTA TTG CTC CTC CCT (518-535) & & & \\
\hline Actin (Actb) & $\begin{array}{l}\text { sense } \\
\text { antisense }\end{array}$ & $\begin{array}{l}\text { GCC AAC CGT GAA AAG ATG A }(419-437) \\
\text { CAA GAA GGA AGG CTG GAA AA }(861-880)\end{array}$ & NM_007393.5 & 54 & 462 \\
\hline PAC1 (ADCYAP1R1) & $\begin{array}{l}\text { sense } \\
\text { antisense }\end{array}$ & $\begin{array}{l}\text { TAT TAC TAC CTG TCG GTG AAG }(912-932) \\
\text { ATG ACT GCT GTC CTG CTC }(1107-1124)\end{array}$ & NM_016989.2 & 49 & 213 \\
\hline VPAC1 (VIPR1) & $\begin{array}{l}\text { sense } \\
\text { antisense }\end{array}$ & $\begin{array}{l}\text { TTT GAG GAT TTC GGG TGC }(974-991) \\
\text { TGG GCC TTA AAG TTG TCG }(1222-1239)\end{array}$ & NM_001097523 & 52 & 266 \\
\hline VPAC2 (VIPR2) & $\begin{array}{l}\text { sense } \\
\text { antisense }\end{array}$ & $\begin{array}{l}\text { CTC CTG GTA GCC ATC CTT }(805-822) \\
\text { ATG CTG TGG TCG TTT GTG }(936-953)\end{array}$ & NM_001014970 & 48 & 149 \\
\hline
\end{tabular}

Table 2. Tables of antibodies used in the experiments,

\begin{tabular}{lllll}
\hline Antibody & Host animal & Dilution & Distributor & SAB2900695 \\
\hline Anti-PAC1 & rabbit, polyclonal & $1: 600$ & Sigma-Aldrich (St. Louis, MO, USA) & AVR-001 \\
Anti-VPAC1 & rabbit, polyclonal & $1: 800$ & Alomone Labs (Jerusalem, Israel) & ab28624 \\
Anti-VPAC2 & rabbit, polyclonal & $1: 600$ & Abcam (Cambridge, UK) & A2228 \\
Anti-actin & mouse, monoclonal & $1: 10,000$ & Sigma-Aldrich & \\
\hline
\end{tabular}

to $10^{-7} \mathrm{M}$. Antagonists of PAC1R/VPAC2R (PACAP6-38, $10^{-7} \mathrm{M}$ ), selective PAC1R $\left(\mathrm{M} 65,10^{-7} \mathrm{M}\right)$, and selective VPAC1R (VIP6-28, $10^{-7} \mathrm{M}$ ) were also used (Bachem). To test endothelium-dependent and endothelium-independent reactions, ACh and SNP (sodium nitroprusside) were administrated $\left(10^{-9}\right.$ to $\left.10^{-6} \mathrm{M}\right)$. The administration of polypeptides was performed as follows: diluted polypeptides were added into a chamber containing $5 \mathrm{~mL}$ of Krebs solution with a micropipette to the intended final concentration $(50 \mu \mathrm{L}$ of $10^{-8}$ to $10^{-4} \mathrm{M}$ of peptide added to the $5-\mathrm{mL}$ chamber, resulting in a $10^{-10}$ to $10^{-6} \mathrm{M}$ concentration of polypeptide).

All drugs were dissolved in distilled water, with the exception of $\mathrm{Ala}^{11,22,28} \mathrm{VIP}$, which was dissolved in $0.1 \mathrm{M}$ of acetic acid. When only the solvent (distilled water or acetic acid) was applied, there was no change in isometric force. Changes in the vasomotor activity were measured by the difference compared to the maximal contraction induced by $60 \mathrm{mM}$ of $\mathrm{KCl}$ (in graphs arkeline, $10^{-\theta} \mathrm{M}$ ) for each administered drug, artery, and genotype of mice.

Measurement of the Isometric Force of Isolated Arteries

The preparation and measurement of the isometric force of isolated CA and FA was performed according to $[23,35]$. After removal of the CA and FA they were quickly transferred into cold oxygenated $\left(95 \% \mathrm{O}_{2} / 5 \% \mathrm{CO}_{2}\right.$; Linde, Repcelak, Hungary) physiological Krebs solution ( $\mathrm{NaCl} 119 \mathrm{mM}, \mathrm{KCl} 4.7$ $\mathrm{mM}, \mathrm{KH}_{2} \mathrm{PO}_{4} 1.2 \mathrm{mM}, \mathrm{NaHCO}_{3} 25 \mathrm{~mm}, \mathrm{Mg}_{2} \mathrm{SO}_{4} 1.2 \mathrm{mM}, \mathrm{CaCl}_{2} \times$ $2 \mathrm{H}_{2} \mathrm{O} 1.6 \mathrm{~mm}$, EDTA $0.026 \mathrm{~mm}$, glucose $\left.11.1 \mathrm{mM}\right) . \mathrm{NaCl}$ and $\mathrm{KCl}$ were purchased from VWR International (Radnor, PA, USA). All

Vasomotor Backup Mechanisms in PACAP Pathways other chemicals and drugs were obtained from Sigma-Aldrich (St. Louis, MO, USA), unless specified otherwise. The arteries were dissected into 2-mm-long rings. Each ring was positioned between 2 tungsten wires (wire diameters were $0.04 \mathrm{~mm}$ for CA and 0.02 $\mathrm{mm}$ for FA) in a $5-\mathrm{mL}$ Krebs bath solution. The bath solution was continuously oxygenated with a gas mixture of $95 \% \mathrm{O}_{2}$ and $5 \%$ $\mathrm{CO}_{2}$, and maintained at $36.9 \pm 0.1^{\circ} \mathrm{C}$.

Isometric contraction forces were measured with a DMT 610 M Wire Myograph (Danish Myo Technology, Aarhus, Denmark). Normalization was performed according to Mulvany and Halpern [35]. LabChart 8 (AD Instruments, Dunedin, New Zealand) and Myodaq 2.01 (Danish Myo Technology) software were used for data acquisition and display, as described previously [23]. After normalization, vessels were allowed to stabilize for $60 \mathrm{~min}$, then 60 $\mathrm{mM}$ of $\mathrm{KCl}$ was administered to establish a tone $[23,36]$. Once the vessel reached the plateau phase, the chosen drug was tested.

\section{RT-PCR Analysis}

Tissues were cryoground in liquid nitrogen and dissolved in Trizol (Applied Biosystems, Foster City, CA, USA), and after the addition of $20 \%$ RNase-free chloroform the samples were centrifuged at $4^{\circ} \mathrm{C}$ at $10,000 \mathrm{~g}$ for $15 \mathrm{~min}$. The samples were incubated in $500 \mu \mathrm{L}$ of RNase-free isopropanol at $-20^{\circ} \mathrm{C}$ for $1 \mathrm{~h}$ then total RNA was harvested in RNase-free water and stored at $-20^{\circ} \mathrm{C}$. The assay mixture for reverse transcriptase reaction contained $2 \mu \mathrm{g}$ of RNA, $0.112 \mu \mathrm{M}$ of oligo(dT), $0.5 \mathrm{mM}$ of dNTP, and 200 units of high-capacity RT (Applied Biosystems) in $1 \times$ RT buffer. Table 1

J Vasc Res

DOI: $10.1159 / 000457798$ 


\section{In Figures 2--5, please confirm the labelling of the $x$-axes [ - $\log (\mathrm{M})$ ], or should the '-' be given to each value, i.e. $-9,-8,-7 \ldots$ etc., or $10^{--0}, 10^{--9}, 10^{--8} \ldots$ etc. -- please clarify.}

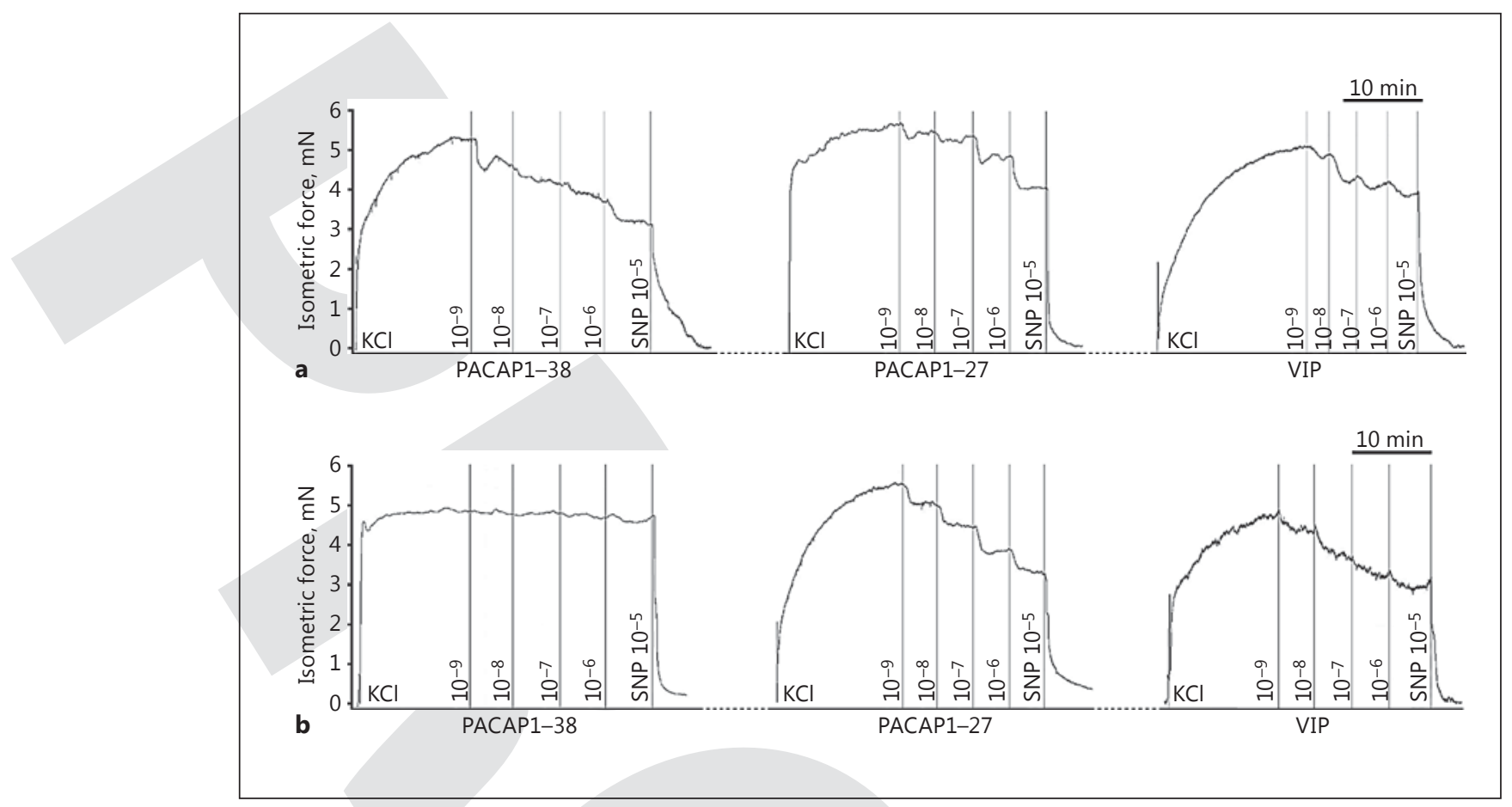

Fig. 1. Original records showing effect of a cumulative of PACAP1-38, PACAP1-27, and VIP in CA of WT $\left(\mathrm{PACAP}^{+/+} ; \mathbf{a}\right)$ and $\mathrm{KO}\left(\mathrm{PACAP}^{-/-} ; \mathbf{b}\right)$ mice. At the end of the experiment, $\operatorname{SNP}\left(10^{-5} \mathrm{M}_{2}\right.$ was administrated to check

details the sequences of primer pairs and polymerase chain reactions. Amplifications were performed in a thermal cycler (Labnet MultiGene $^{\mathrm{TM}}$ 96-well Gradient Thermal Cycler; Labnet International, Edison, NJ, USA) in a final volume of $21 \mu \mathrm{L}$ (containing 1 $\mu \mathrm{L}$ of forward and reverse primers [0.4 $\mu \mathrm{M}$ ], $0.5 \mu \mathrm{L}$ of dNTP [200 $\mu \mathrm{M}]$, and 5 units of Promega GoTaq ${ }^{\circledR}$ DNA polymerase in $1 \times$ reaction buffer) as follows: $95^{\circ} \mathrm{C}, 2 \mathrm{~min}$, followed by 35 cycles (denaturation, $94^{\circ} \mathrm{C}, 1 \mathrm{~min}$; annealing at optimized temperatures as given in Table 1 for $1 \mathrm{~min}$; extension, $72^{\circ} \mathrm{C}, 90 \mathrm{~s}$ ) and then $72^{\circ} \mathrm{C}, 10$ min. PCR products were analyzed by electrophoresis in $1.2 \%$ agarose gel containing ethidium bromide. Actin was used as the internal control. Signals were developed with a gel documentary system (FluorChem E; ProteinSimple, San Jose, CA, USA). The optical density of signals was measured using ImageJ $1.40 \mathrm{~g}$ freeware and the results were normalized to the optical density of control tissue.

\section{Western Blot Analysis}

Isolated FA and $\mathrm{CA}$ were washed in physiological $\mathrm{NaCl}$ solution then collected in $100 \mu \mathrm{L}$ of homogenization RIPA (radio immunoprecipitation assay) buffer ( $150 \mathrm{mM}$ sodium chloride, $1.0 \%$ NP40, $0.5 \%$ sodium deoxycholate, $50 \mathrm{~mm}$ Tris, $\mathrm{pH}$ 8.0) containing protease inhibitors (Aprotinin, $10 \mu \mathrm{g} / \mathrm{mL}$ ), benzamidine $(5 \mathrm{mM})$, leupeptin $(10 \mu \mathrm{g} / \mathrm{mL})$, trypsine inhibitor $(10 \mu \mathrm{g} / \mathrm{mL})$, PMSF $(1$ $\mathrm{mM})$, EDTA (5 mM), EGTA (1 mM), Na-fluoride (8 mM), and Naorthovanadate $(1 \mathrm{mM})$. The samples were stored at $-70^{\circ} \mathrm{C}$. Measurements were repeated 3 times for each vessel, isolated from WT and $\mathrm{KO}$ mice ( $n=3$ /group). Artery samples were first mechanically ground, then the suspensions were sonicated by a pulsing burst for $30 \mathrm{~s}$ at $40 \mathrm{~A}$ (Cole-Parmer, Vernon Hills, IL, USA). For Western blotting, total tissue lysates were used. Samples for SDSPAGE were prepared by the addition of Laemmli electrophoresis sample buffer (4\% SDS, 10\% 2-mercaptoethanol, 20\% glycerol, $0.004 \%$ bromophenol blue, $0.125 \mathrm{M}$ Tris $\mathrm{HCl} \mathrm{pH} 6.8$ ) to tissue lysates to set an equal protein concentration of samples, and boiled for $10 \mathrm{~min}$.

A total of $20 \mu \mathrm{g}$ of protein was separated by $10 \%$ SDS-PAGE gel for the detection of PAC1, VPAC1, and VPAC2. Proteins were transferred electrophoretically to nitrocellulose membranes. After blocking in 5\% nonfat dry milk in PBST (phosphate-buffered saline with $0.1 \%$ Tween $20 ; 20 \mathrm{mM} \mathrm{Na}_{2} \mathrm{HPO}_{4}, 115 \mathrm{mM} \mathrm{NaCl}, \mathrm{pH} 7.4$ ), the membranes were washed and exposed to the primary antibodies overnight at $4^{\circ} \mathrm{C}$. Polyclonal anti-PAC1 antibody (Sigma-Aldrich) in 1:500, polyclonal anti-VPAC1 antibody (Alomone Labs, Jerusalem, Israel) in $1: 1,000$ and polyclonal anti-VPAC2 antibody (Abcam, Cambridge, UK) in 1:800 dilutions were used (Table 2). After washing 3 times for 10 min with PBST, the membranes were incubated with the secondary antibody, anti-rabbit IgG (Bio-Rad Laboratories, Hercules, CA, USA) in a 1:1,500 dilution in PBST containing $1 \%$ nonfat dry milk for $2 \mathrm{~h}$ at room temperature. Signals were detected by enhanced chemiluminescence (Advansta Inc., Menlo Park, CA, USA) according to the instructions of the manufacturer. Actin was used as the internal control. The optical density of signals was measured using ImageJ $1.40 \mathrm{~g}$ freeware and the results were normalized to the optical density of control tissue. Signals were developed with a gel documentary system (Fluorchem E; ProteinSimple). 

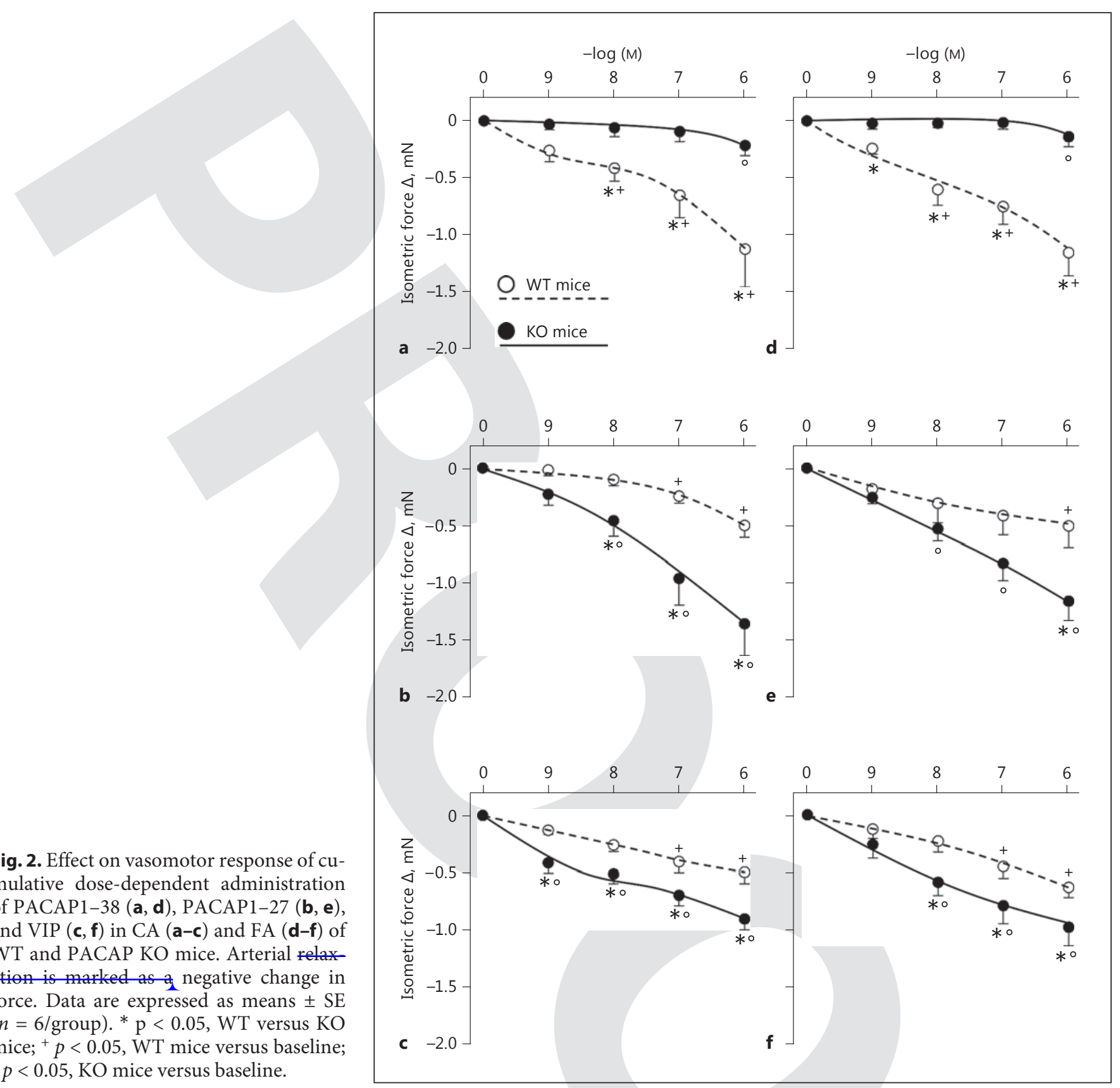

Fig. 2. Effect on vasomotor response of cumulative dose-dependent administration of PACAP1-38 (a, d), PACAP1-27 (b,e), and $\operatorname{VIP}(\mathbf{c}, \mathbf{f})$ in $\mathrm{CA}(\mathbf{a}-\mathbf{c})$ and FA $(\mathbf{d}-\mathbf{f})$ of $\mathrm{WT}$ and PACAP KO mice. Arterial ation is marked as a negative change in force. Data are expressed as means \pm SE ( $n=6$ /group). ${ }^{*} \mathrm{p}<0.05, \mathrm{WT}$ versus $\mathrm{KO}$ mice; ${ }^{+} p<0.05$, WT mice versus baseline; ${ }^{\circ} p<0.05$, KO mice versus baseline.

\section{Statistical Analysis}

All data collected as time series were compared across genotypes and dose points by 2-way ANOVA (Tukey post hoc). All data were collected as single-point measurements. For Western blot analysis, the Student $t$ test was used. Analyses were performed using Sigma Plot 12.5 (Systat, Chicago, IL, USA). Differences were considered significant at $p<0.05$. Data are reported as the mean \pm SE. Additional information can be found in the online supplementary material (see www.karger.com/doi/10.1159/000457798 for all online suppl. material).

Vasomotor Backup Mechanisms in PACAP Pathways

\section{Results}

Effect of Cumulative Doses of PACAP1-38, PACAP1-27, and VIP on the Isometric Force Development of Isolated Arteries

First, we obtained the responses of arteries to PACAP1-38, PACAP1-27, and VIP in WT and KO mice. Original records (Fig. 1) and summary data (Fig. 2) show the vasomotor effects to the cumulative doses of PA- 


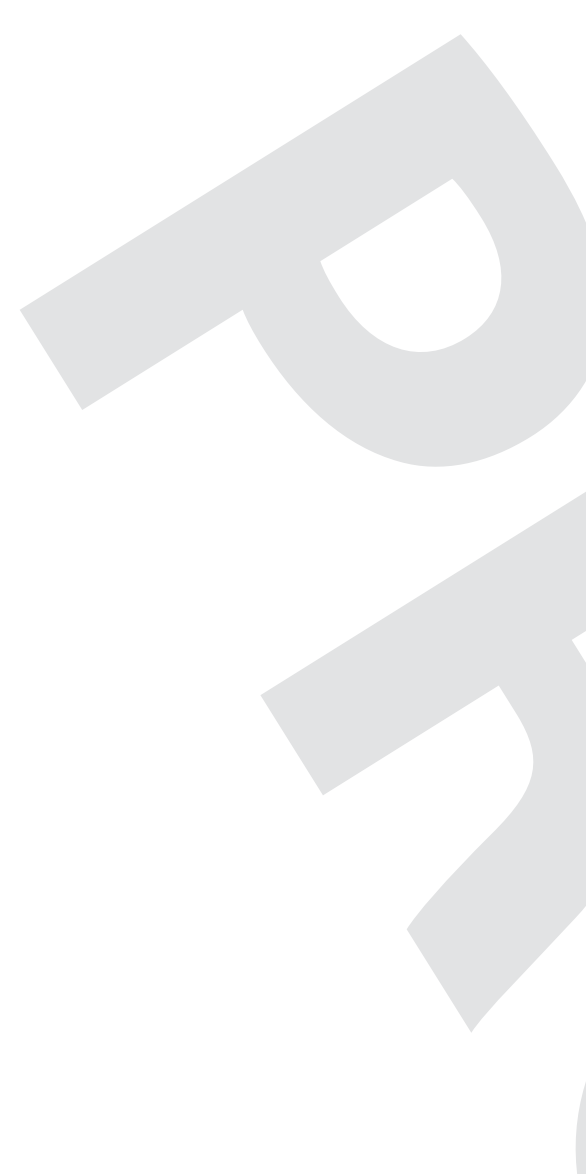

Fig. 3. Effect on vasomotor response of cumulative dose-dependent administration of maxadilan (a, d), $\mathrm{Ala}^{11,22,28} \mathrm{VIP}(\mathbf{b}, \mathbf{e})$, and Bay55-9837 (c, f) in CA (a-c) and FA (d-f) of WT and PACAP KO mice, and their effect in the presence of M65 (PAC1R agonist; $\mathbf{a}, \mathbf{d}$ ) and VIP6-28 (VPAC1R agonist; $\mathbf{b}, \mathbf{e})$. A negative change in force is marked as arterial relaxation. Data are expressed as means $\pm \mathrm{SE}$ ( $n=3-6$ /group). ${ }^{*} p<0.05$, WT versus $\mathrm{KO} ;{ }^{+} p<0.05$, WT versus baseline; ${ }^{\circ} p<0.05$, KO versus baseline; ${ }^{\dagger} p<0.05$, WT + M65 versus baseline; ${ }^{\Delta} p<0.05, \mathrm{KO}+\mathrm{M} 65$ versus baseline; ${ }^{*} p<0.05$, Ala $^{11,22,28}$ VIP versus Ala ${ }^{11,22,28}$ VIP + VIP6-28 (in WT mice).

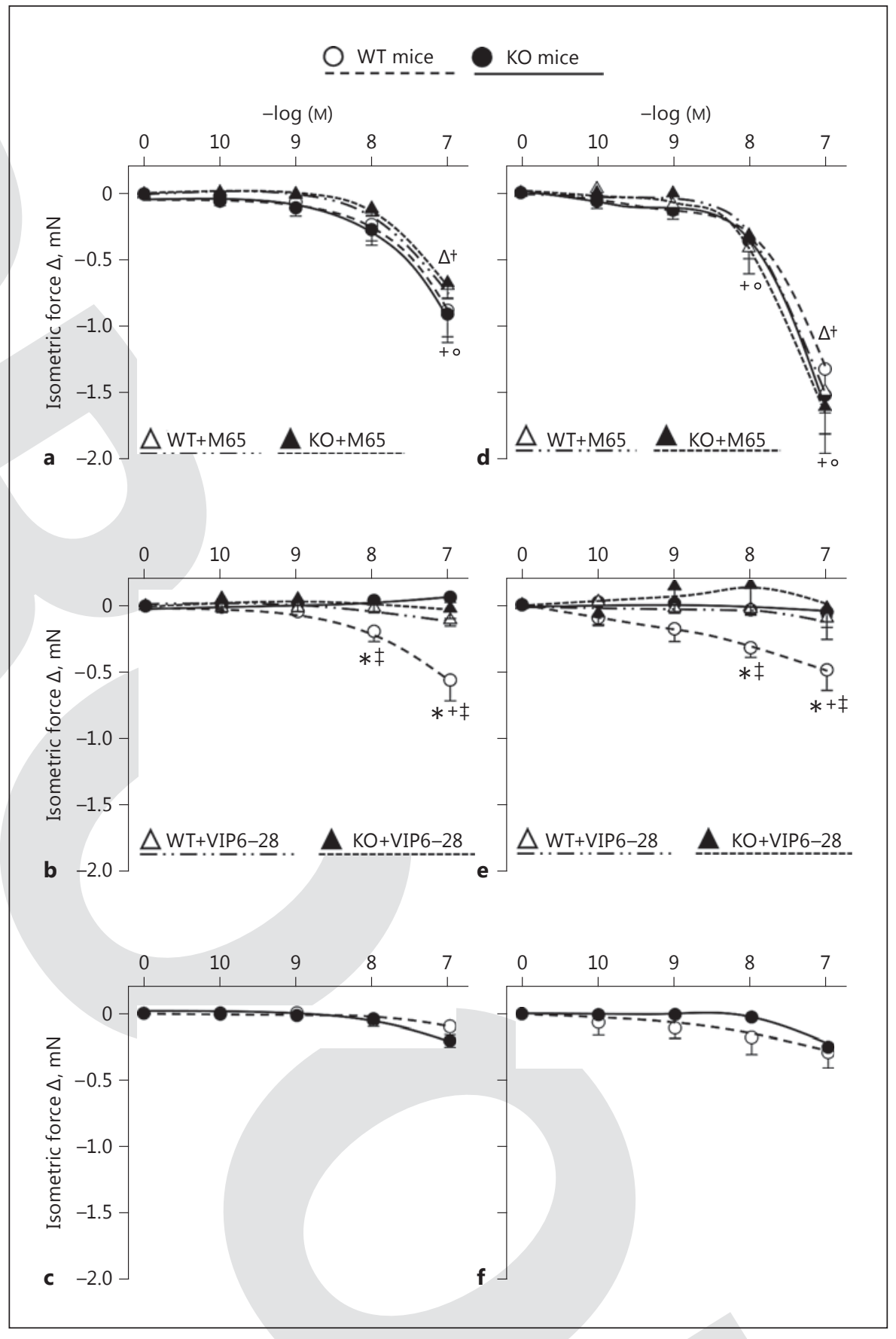

CAP1-38, PACAP1-27, and VIP in the isolated CA (Fig. $2 \mathrm{a}-\mathrm{c}$ ) of WT and KO mice. In the arteries of WT mice, PACAP1-38 $\left(10^{-8}\right.$ to $\left.10^{-6} \mathrm{M}\right)$ elicited a significantly greater dose-dependent relaxation than PACAP1-27 and VIP. In contrast, PACAP1-27 and VIP (Fig. 2b, c) elicited significantly greater dose-dependent relaxations of arteries from KO mice that of WT mice, whereas in arter- ies from $\mathrm{KO}$ mice, PACAP1-38-induced relaxations were significantly reduced (only the highest dose resulted in relaxation; Fig. 2a). In FA of WT and KO mice, PACAPand VIP-induced responses were similar to those of CA (Fig. 2d-f). 


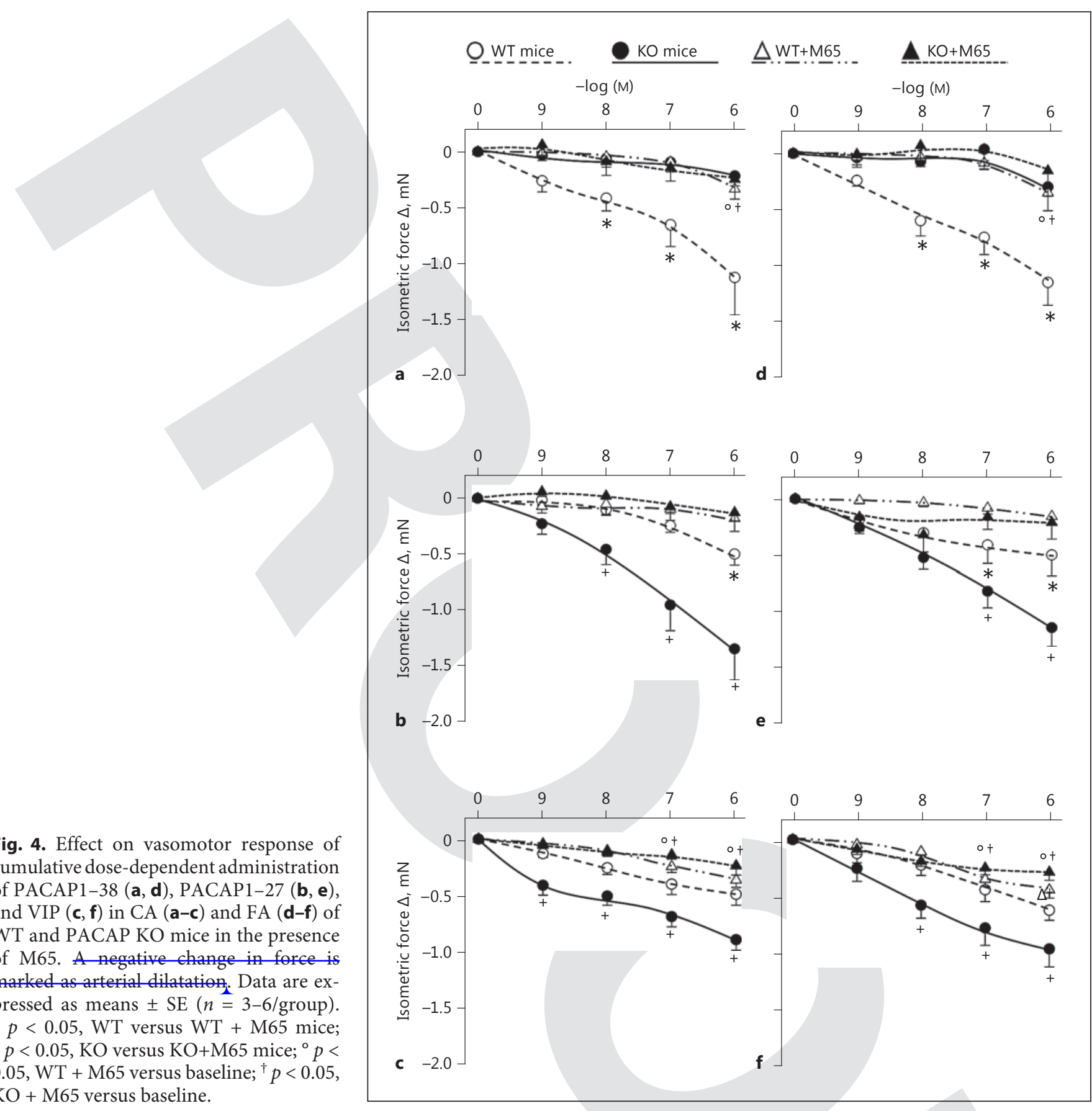

Fig. 4. Effect on vasomotor response of cumulative dose-dependent administration of PACAP1-38 (a, d), PACAP1-27 (b, e), and VIP $(\mathbf{c}, \mathbf{f})$ in CA $(\mathbf{a}-\mathbf{c})$ and FA $(\mathbf{d}-\mathbf{f})$ of WT and PACAP KO mice in the presence of M65. A negative change in force is marked as arterialdilation. Data are expressed as means \pm SE ( $n=3-6$ /group). ${ }^{*} p<0.05$, WT versus WT + M65 mice; $p<0.05, \mathrm{KO}$ versus $\mathrm{KO}+\mathrm{M} 65$ mice; ${ }^{\circ} p<$ $\mathrm{KO}+\mathrm{M} 65$ versus baseline.

Effect of Cumulative Doses of Maxadilan, Ala ${ }^{11,22,28}$ VIP, and Bay55-9837 on the Isometric Force Development of Isolated Arteries in the Presence of M65 and VIP6-28

Summary data show the vasomotor effects of cumulative doses of receptor agonists in the CA (Fig. $3 \mathrm{a}-\mathrm{c}$ ) and FA (Fig. 3d-f) of WT and KO mice and their responses in

Vasomotor Backup Mechanisms in PACAP Pathways the presence of selective blockers. Maxadilan induced significant and similar relaxations of CA $\left(10^{-7} \mathrm{M}\right)$ and FA $\left(10^{-8}\right.$ to $\left.10^{-7} \mathrm{M}\right)$ isolated from WT and KO mice (Fig. 3a, d). However, the presence of M65 had no effect on vasomotor response to maxadilan-induced relaxation in either CA or FA. Ala ${ }^{11,22,28}$ VIP elicited a significant relaxation in the arteries of WT mice $\left(10^{-7} \mathrm{M}\right)$, whereas it elic- 


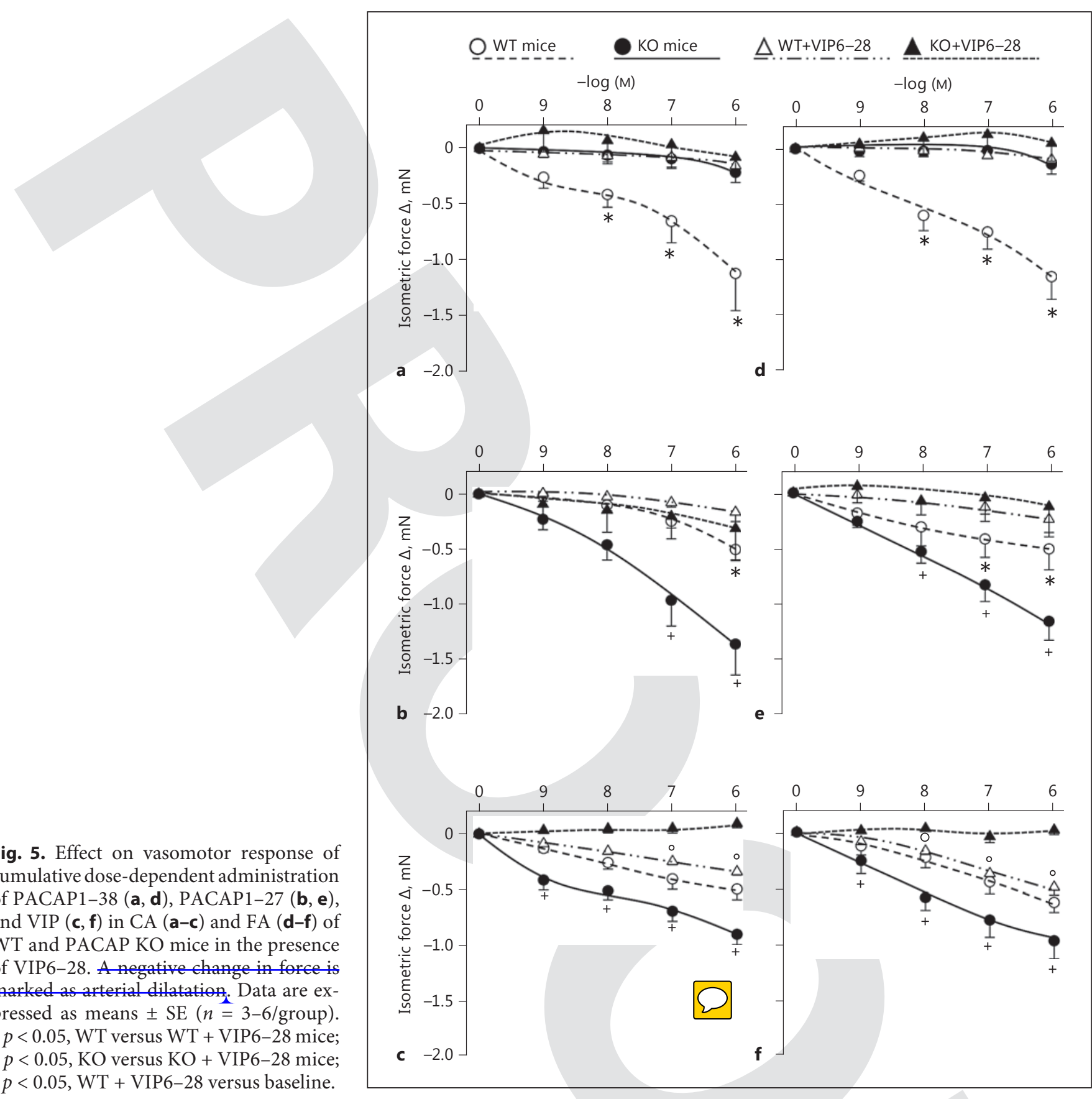

Fig. 5. Effect on vasomotor response of cumulative dose-dependent administration of PACAP1-38 (a, d), PACAP1-27 (b, e), and VIP $(\mathbf{c}, \mathbf{f})$ in CA $(\mathbf{a}-\mathbf{c})$ and FA $(\mathbf{d}-\mathbf{f})$ of $\mathrm{WT}$ and PACAP KO mice in the presence of VIP6-28. A negative change in force is marked as arterial dilatation. Data are expressed as means $\pm \mathrm{SE}(n=3-6 /$ group $)$ $* p<0.05$, WT versus WT + VIP6-28 mice; ${ }^{+} p<0.05, \mathrm{KO}$ versus $\mathrm{KO}+\mathrm{VIP} 6-28$ mice ${ }^{\circ} p<0.05$, WT + VIP6-28 versus baseline.

ited no response in arteries from KO mice (Fig. 3b, e). A significant difference in the response between $\mathrm{WT}$ and $\mathrm{KO}$ mice was found at the 2 highest doses $\left(10^{-8}\right.$ to $\left.10^{-7} \mathrm{M}\right)$. Moreover, the selective blocker VIP6-28 blocked the $\mathrm{Ala}^{11,22,28} \mathrm{VIP}$-induced relaxation, which was significant at the 2 highest doses of $\mathrm{Ala}^{11,22,28} \mathrm{VIP}\left(10^{-8}\right.$ to $\left.10^{-7} \mathrm{M}\right)$. Bay55-9837 did not elicit a significant vasomotor response in the arteries from WT or KO mice (Fig. 3c, f).

\section{Effect of Cumulative Doses of PACAP1-38,} PACAP1-27, and VIP on the Isometric Force Development of Isolated Arteries in the Presence of M65

Summary data show the effect of cumulative doses of PACAP1-38, PACAP1-27, and VIP in the presence of M65 in the CA (Fig. 4a-c) and FA (Fig. 4d-f) of WT and $\mathrm{KO}$ mice. The presence of M65 significantly reduced PA-
8
Ivic/Fulop/Juhasz/Reglodi/Toth/ Hashimoto/Tamas/Koller 
In the following from the Results section, please confirm the change from 'KO $\mathbf{0 . 6}$ ' to 'FA 0.6': CA 0.2 , and FA 0.6 ; $p<$ 0.05 vs. WT -- also, are these values correct and adequately explained?

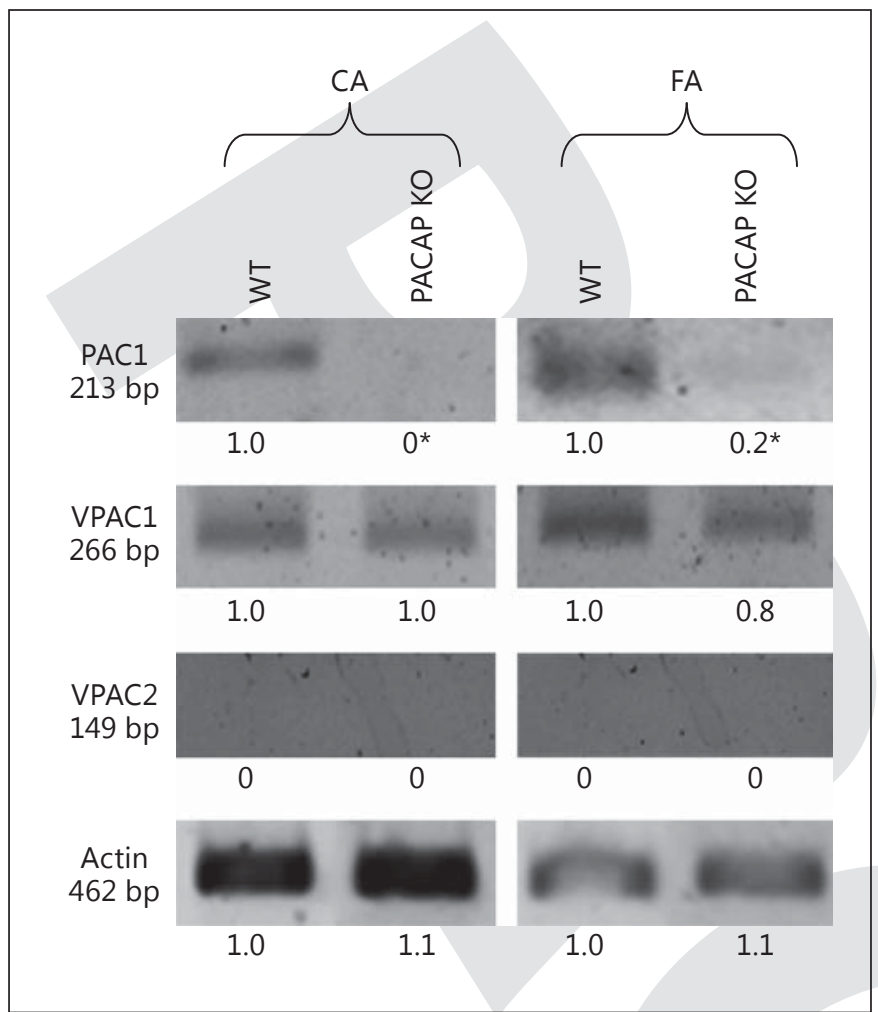

Fig. 6. mRNA expression of PAC1, VPAC1, and VPAC2 in FA and CA of WT and PACAP KO mice. Actin was used as a control. The numbers below the signals represent integrated densities ef signals determined by ImageJ software. mRNA expression of representative data for 2 independent arterial/animal samples. ${ }^{*} p<0.05$ versus control.

CAP1-38-induced relaxations of arteries from WT mice (up to $10^{-6} \mathrm{M}$ ), whereas it did not affect the arterial responses of KO mice (Fig. 4a, d). M65 significantly reduced PACAP1-27-induced relaxations of arteries from WT mice, and also eliminated the increased arterial responses of KO mice (Fig. 4b, e). M65 significantly reduced VIP-induced relaxations of arteries from $\mathrm{KO}$ mice $\left(10^{-8}\right.$ to $\left.10^{-6} \mathrm{M}\right)$, whereas it did not significantly affect the arterial responses of WT mice (Fig. 4c, f).

\section{Effect of Cumulative Doses of PACAP1-38,}

PACAP1-27, and VIP on the Isometric Force

Development of Isolated Arteries in the

Presence of VIP6-28

Summary data show the effect of cumulative doses of PACAP1-38, PACAP1-27, and VIP in the presence of VIP6-28 in the CA (Fig. 5a, c) and FA (Fig. 5c, f) of WT and KO mice. The presence of VIP6-28 significantly reduced PACAP1-38-induced relaxations of arteries from

Vasomotor Backup Mechanisms in PACAP Pathways
WT mice, whereas it did not affect the already reduced arterial responses of $\mathrm{KO}$ mice (Fig. 5a, d). VIP6-28 significantly reduced PACAP1-27-induced relaxations of arteries from WT mice, and also eliminated the increased arterial responses of KO mice (Fig. 5b, e). VIP6-28 significantly blocked VIP-induced relaxations of arteries from $\mathrm{KO}$ mice $\left(10^{-9}\right.$ to $\left.10^{-6} \mathrm{M}\right)$, whereas it did not significantly affect the arterial responses of WT mice (Fig. 5c, f).

Expression Levels of PAC1, VPAC1, and VPAC2 in the Arteries of WT and KO Mice

The protein and mRNA expressions of PAC1, VPAC1, and VPAC2 were measured in CA and FA of WT and $\mathrm{KO}$ mice. We detected a weak mRNA signal of PAC1 in the arteries in both groups. Statistical analysis $(t$ test, $* p<$ 0.05 vs. control) showed significantly reduced PAC1 expression levels in the arteries of $\mathrm{KO}$ mice, in both CA and FA. The expression of VPAC1R was shown in all groups of arteries in WT and $\mathrm{KO}$ mice, whereas the expression of VPAC2R was not detected in either group (Fig. 6). Protein levels, as detected by Western blot, corresponded with the mRNA levels - a significant reduction of PAC1R was found in $\mathrm{KO}$ mice (CA 0.2, and FA $0.6 ; p<0.05$ vs. $\mathrm{WT}$ ), whereas VPAC1 did not change, and VPAC2 was not detected in either group.

Effect of Cumulative Doses of PACAP1-38,

PACAP1-27, and VIP on the Isometric Force

Development of Isolated Arteries in the Presence of

Cumulative Pharmacological Blockade of PAC1R,

VPAC1R, and VPAC2R (PACAP6-38)

Cumulative doses of PACAP1-38, PACAP1-27, and VIP did not elicit changes in the vasomotor tone of arteries in the presence of antagonist PACAP6-38 (online suppl. Fig. 1).

KCl-Induced Constrictions of Arteries

$\mathrm{KCl}(60 \mathrm{mM})$ elicited contractions of arteries, which were significantly greater in the arteries of $\mathrm{KO}$ mice (online suppl. Fig. 2a).

Relaxations Induced by Endothelium-Dependent and -Independent Agonists

ACh (an endothelium-dependent agent) and SNP (an endothelium-independent agent) elicited relaxations of arteries isolated from WT and KO mice. The SNPinduced relaxations were significantly greater in both arteries of WT mice compared to the KO mice (at $10^{-7} \mathrm{M}$ and $10^{-6} \mathrm{M}$ ), whereas the magnitude of ACh-induced responses were not different (online suppl. Fig. 2b, c).

J Vasc Res

DOI: $10.1159 / 000457798$ 


\section{Discussion}

The novel findings of the present study are: (1) PACAP1-38 elicited significantly greater relaxations in the arteries of WT mice than PACAP1-27 and VIP; (2) in contrast, PACAP1-38 did not induce relaxation in the arteries of KO mice, whereas PACAP1-27 and VIP induced significantly greater relaxations compared to the arterial responses of WT mice; (3) maxadilan, a selective PAC1R agonist, elicited arterial relaxations in both WT and $\mathrm{KO}$ mice, whereas Ala ${ }^{11,22,28} \mathrm{VIP}$, a selective VPAC1R agonist, elicited arterial relaxations only in WT mice; and (4) in the arteries of WT mice, both selective antagonists (PAC1R and VPAC1R) reduced the relaxations to PACAP and VIP, whereas, in the arteries of KO mice, PAC1R antagonist reduced the relaxations and VPAC1R antagonist blocked the relaxations induced by PACAP and VIP.

\section{PACAP- and VIP-Induced Vasomotor Responses in}

Arteries from WT and KO Mice

The polypeptide PACAP has been shown to be a multifunctional molecule with several regulatory roles $[1,37]$. These diverse functions also include potent vasomotor effects $[17,18]$. There are studies showing relaxations to both PACAP isoforms and VIP in vessels of different origin, such as carotid [23], pulmonary [24], mesenteric and coronary [38], meningeal [20], cerebral and intracerebral $[21,22]$, and middle cerebral arteries [10] of various species. Similarly, we also observed relation significantly greater in response to PACAP1-38 as compared to PACAP1-27 and VIP in both arteries of WT mice. These findings confirmed the observation of Huang et al. [38], who showed that PACAP1-38 elicited the greatest dilator response in rat mesenteric arteries. However, the same authors also found that PACAP1-38 was less potent than VIP or PACAP1-27 in porcine coronary arteries, suggesting region-specific PACAP signaling in vasomotor responses. Indeed, vessels originating from different regions can respond to the same stimulus with different magnitudes [23], or react differently even if vessels are from the same organ, such as the brain [10]. Although different in origin, $\mathrm{CA}$ and $\mathrm{FA}$ are considered to be "large arteries" as compared to "small" brain arteries, for example. Region-specific responses have also been observed by others [22, 23, 38, 39], which may be due to different/similar sensitivities to PACAP isoforms showing an important region specificity [39] of arteries, reflecting different requirements of blood supply to different regions.

The genetic modification allows the assessment of endogenous regulatory functions of PACAP isoforms by
PACAP-induced responses of KO mice. Like in WT, PA$\mathrm{CAP}$ and VIP induce relaxation in $\mathrm{KO}$ mice, but in a different pattern. We found a "biological switch" between PACAP1-38 and PACAP1-27/VIP, meaning that PACAP1-27/VIP took over the physiological response, i.e., relaxation from PACAP1-38. Although PACAP is not prested in KO mice, the identical responses of PACAP1-27 (artifially administrated) and VIP (since their structure is $68 \%$ identical [1]) indicate the importance of backup mechanisms the VIP system.

Only recent reports address the cardiovascular consequences of PACAP deficiency [20,32], showing that lack of PACAP causes developmental defects and impaired protection against harmful stimuli. In contrast, there are no reports yet regarding the effects of PACAP in the peripheral vasculature of PACAP-deficient mice.

\section{Role of PAC1, VPAC1, and VPAC2Rs in Vasomotor Responses}

The distribution of PACAP/VIP receptors can vary greatly in different organs and even within the same organ [1]. Vessel walls are highly innervated by PACAP-containing nerve fibers, and a high density of PACAP/VIP binding sites has been reported in the arteries or humans and rats $[1,10,22,40,41]$. However, the presence of PAC1, VPAC1, and VPAC2 in peripheral arteries of mice and their roles in the vasomotor response are less known.

In the present study, using maxadilan, we showed the involvement of PAC1 R in mediating the vasomotor activity of PACAP, confirming the findings of many others [ 1 , 23]. Relaxations elicited by maxadilan were similar in the arteries of WT and KO mice, despite the differences in mRNA and protein levels of PAC1Rs. It is unclear why maxadilan induced a similar magnitude of response, but it could be due to its greater potency [1]. This is not unexpected since Otto et al. [42] have already shown the crucial importance of PAC1R in maintaining vascular tone, indicating the presence of PAC1Rs. In addition, PACAP regulates PAC1R expression $[43,44]$, and absence of PACAP protein could be the reason for the differences in mRNA expression and protein levels between the arteries of WT and KO mice (and also for the different responses to PACAP1-38, but not to maxadilan). Hoover et al. [45] showed that both maxadilan and PACAP1-27 activate PAC1R located on cardiac neurons; however, they differ in downstream signaling, indicating their importance. This suggests that PAC1R could be modified with its potency preserved. Interestingly, maxadilan-induced relaxations were not affected by M65, an inhibitor of PAC1R, possibly because maxadilan is several thou-
10

J Vasc Res

DOI: $10.1159 / 000457798$
Ivic/Fulop/Juhasz/Reglodi/Toth/

Hashimoto/Tamas/Koller 


\section{Please confirm the changes made to Fig. 7 legend. Thank you.}

sand-fold more potent than M65, or due to the existence of splice variants [1] with different affinities for maxadilan and M65. One can also assume that maxadilan may not be selective enough [46].

The arteries of WT mice also responded with relaxations to a selective VPAC1R agonist, confirming the presence of a receptor. Another study also reported the presence of a receptor in mice in different tissues of the central nervous system [47], indicating the importance of VPAC1R. Although the mRNA and protein levels revealed no difference between the arteries of WT and $\mathrm{KO}$ mice, the vasomotor response to the agonist $\left(\mathrm{Ala}^{11,22,28} \mathrm{VIP}\right)$ was absent in $\mathrm{KO}$ mice. We propose that the absence of PACAP protein elicited alternations in either the function or signaling pathway of VPAC1R, which is reflected in different responses to agonists and, consequently, in different responses of arteries of WT and KO mice. Importantly, PACAP, compared to VIP, has greater potential for regulation of the expression of PACAP/ VIP receptors [43], which can be altered by lack of PACAP in favor of VIP. It seems, however, that VPAC2R does not play a role in PACAP- and VIP-induced vasomotor responses of peripheral arteries.

We made observation with PACAP isoforms and VIP in the presence of PAC1R and VPAC1R antagonists, indicating that in WT mice the PACAP- and VIP-induced relaxations of arteries most likely need both PAC1R and VPAC1R to achieve a maximal response. When PACAP protein is not presented ( $\mathrm{KO}$ mice) the VPAC1R may undergo conformational changes, allowing the more effective binding of VIP (Fig. 7), which may explain why the blockade of PAC1R results in the reduction of relaxation and the blockade of VPAC1R results in the abolishment of relaxation. Nevertheless, these findings indicate that arterial relaxations in WT mice are mediated primarily via VPAC1R, as was shown previously [10].

\section{KCl-Induced Tone of Arteries of WT and KO Mice}

We used $\mathrm{KCl}$ to test the contractile abilities of arteries because it elicits responses without receptor mediation, which may change in various conditions and animals [36]. $\mathrm{KCl}$ induced greater arterial tone, which could be due to increased oxidative stress [48], shown to be present in KO mice [31], and/or due to the absence of PACAP, which can interfere with the vasomotor properties of arteries by reducing cAMP activity, which is normally activated by PACAP [49]. The increased tone elicited by $\mathrm{KCl}$ and/or oxidative stress could also be responsible for reduced responses of arteries of $\mathrm{KO}$ mice to the $\mathrm{NO}$ donor

Vasomotor Backup Mechanisms in PACAP Pathways
Receptor activation in arteries of PACAP (WT) mice

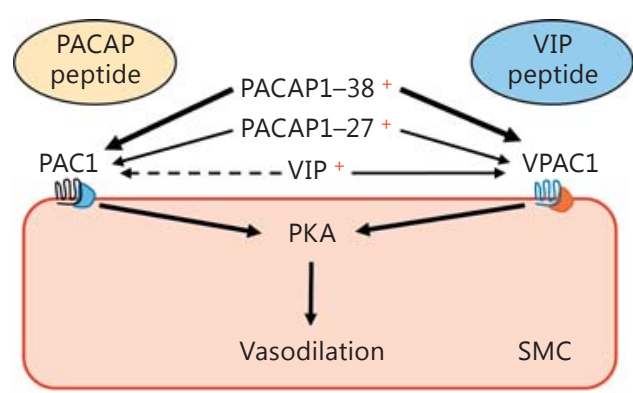

Receptor activation in arteries of PACAP-deficient (KO) mice

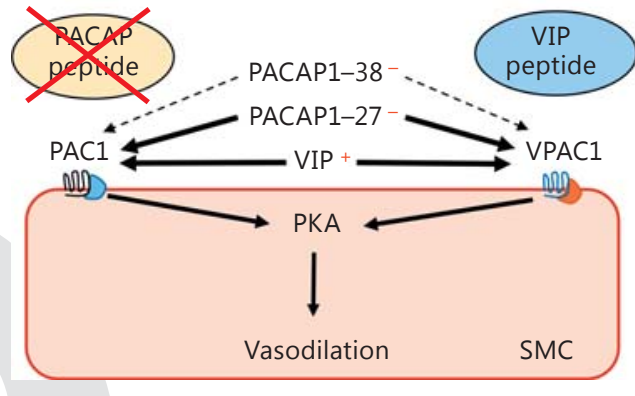

Fig. 7. Proposed mechanisms of PACAP-induced in PACAP WT and KO mice. Upper panel: as described by Koide et al. [50], PACAP and VIP bind to PAC1R/VPAC1R, the G proteincoupled receptors, and stimulate $\mathrm{CAMP} / \mathrm{PKA}$, promoting vasodilatation. PACAP isoforms bind to both receptors, while VIP binds only to VPAC1R (or VIP to PAC1 at $>500 \mathrm{nM}$ ) [1]. Increased and reduced relaxations to polypeptides are marked with thicker and thinner arrows, respectively, as compared to PACAP1-38. Lower panel: in PACAP-deficient mice, PACAP1-38 does not elicit relaxations, whereas PACAP1-27 and VIP elicit relaxations. This could be explained by previous findings [2-4] that the molecular structure of PACAP1-27 and VIP are 68\% similar, thus PACAP1-27 can mimic VIP (and thus induces relaxation), and exogenous polypeptides can elicit relaxation in PACAP deficiency. Our data suggest that endogenous VIP can bind not only to VPAC1R, but also to PAC1R. Increased, reduced, or absent relaxations to polypeptides are marked with thicker, thinner, or dashed arrows, respectively (as compared to the PACAP WT mice). "+" indicates polypeptides presented in the cell and added exogenously; " -" indicates exogenously added polypeptides (in PACAP-deficient mice only).

SNP. These findings could have physiological importance since PACAP can provide a counterbalance mechanism for vasoconstriction, as manifested by many pathological conditions [31], such as the presence of hypertension in $\mathrm{PAC} \mathrm{R}^{-/-}$mice [42].

J Vasc Res 11 


\section{Conclusions}

This study is the first to show the vasomotor effects of exogenous PACAP1-38, PACAP1-27, and VIP polypeptides in peripheral arteries isolated from PACAP-deficient mice, in which relaxations of arteries to PACAP1-38 were absent, whereas relaxations to PACAP1-27 and VIP were augmented. The vasomotor responses to these polypeptides were mediated by PAC1 and VPAC1Rs, the activities of which were dependent on the presence of endogenous PACAP. In PACAP deficiency, alternative pathways maintained the relaxations of arteries, underlining the physiological importance of PACAP vascular signaling.

\section{References}

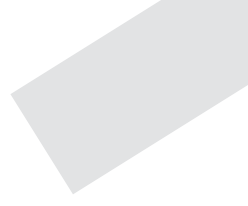

1 Vaudry D, Falluel-Morel A, Bourgault S, Basille M, Burel D, Wurtz O, Fournier A, Chow BK, Hashimoto H, Galas L, Vaudry H: Pituitary adenylate cyclase-activating polypeptide and its receptors: 20 years after the discovery. Pharmacol Rev 2009;61:283-357.

2 Broyart JP, Dupont C, Laburthe M, Rosselin G: Characterization of vasoactive intestinal peptide receptors in human colonic epithelial cells. J Clin Endocrinol Metab 1981;52:715721.

3 Campbell RM, Scanes CG: Evolution of the growth hormone-releasing factor (GRF) family of peptides. Growth Regul 1992;2:175191.

4 Segre GV, Goldring SR: Receptors for secretin, calcitonin, parathyroid hormone (PTH)/ $\mathrm{PTH}$-related peptide, vasoactive intestinal peptide, glucagonlike peptide 1, growth hormone-releasing hormone, and glucagon belong to a newly discovered G-protein-linked receptor family. Trends Endocrinol Metab 1993;4:309-314.

5 Laburthe M, Couvineau A: Molecular pharmacology and structure of VPAC receptors for VIP and PACAP. Regul Pept 2002;108: 165-173.

6 Laburthe M, Couvineau A, Tan V: Class II $G$ protein-coupled receptors for VIP and PACAP: structure, models of activation and pharmacology. Peptides 2007;28:1631-1639.

7 Lutz EM, MacKenzie CJ, Johnson M, West K, Morrow JA, Harmar AJ, Mitchell R: Domains determining agonist selectivity in chimaeric VIP2 (VPAC2)/PACAP (PAC1) receptors. Br J Pharmacol 1999;128:934-940.

8 Köves K, Arimura A, Görcs TG, SomogyváriVigh A: Comparative distribution of immunoreactive pituitary adenylate cyclase activating polypeptide and vasoactive intestinal polypeptide in rat forebrain. Neuroendocrinology 1991;54:159-169.

\section{Acknowledgments}

The following are acknowledged for their support: Hungarian National Science Research Fund (OTKA) K104984, K119759, KTIA_13_NAP-A-III/5 and PTE ÁOK KA Research Grant (D.R. and A.T.) and K108444 (A.K.); FP7 Marie Curie project - Small Artery Remodeling (SmART) ITN (I.I. and A.K.); Bolyai János Scholarship, Szodoray Lajos and Magyary Zoltán Funds by the European Union and the State of Hungary, University of Debrecen (RH/751/2015; T.J.); and the JSPS KAKENHI and Program (S2603; H.H.).

\section{Disclosure Statement}

The authors declare that they have no conflicts of interest.
9 Légrádi G, Shioda S, Arimura A: Pituitary adenylate cyclase-activating polypeptide-like immunoreactivity in autonomic regulatory areas of the rat medulla oblongata. Neurosci Lett 1994;176:193-196.

10 Baun M, Hay-Schmidt A, Edvinsson L, Olesen J, Jansen-Olesen I: Pharmacological characterization and expression of VIP and PACAP receptors in isolated cranial arteries of the rat. Eur J Pharmacol 2011;670:186-194.

11 Chartrel N, Tonon MC, Vaudry H, Conlon JM: Primary structure of frog pituitary adenylate cyclase-activating polypeptide (PACAP) and effects of ovine PACAP on frog pituitary. Endocrinology 1991;129:3367-3371.

12 Hoyle CH: Neuropeptide families: evolutionary perspectives. Regul Pept 1998;73:1-33.

13 Sherwood NM, Krueckl SL, McRory JE: The origin and function of the pituitary adenylate cyclase-activating polypeptide (PACAP)/glucagon superfamily. Endocr Rev 2000;21:619670.

14 Banki E, Sosnowska D, Tucsek Z, Gautam T, Toth P, Tarantini S, Tamas A, Helyes Z, Reglodi D, Sonntag WE, Csiszar A, Ungvari Z: Age-related decline of autocrine pituitary adenylate cyclase-activating polypeptide impairs angiogenic capacity of rat cerebromicrovascular endothelial cells. J Gerontol A Biol Sci Med Sci 2015;70:665-674.

15 Minkes RK, McMahon TJ, Higuera TR, Murphy WA, Coy DH, Kadowitz PJ: Analysis of systemic and pulmonary vascular responses to PACAP and VIP: role of adrenal catecholamines. Am J Physiol 1992;263:H1659H1669.

16 Moller K, Sundler F: Expression of pituitary adenylate cyclase activating peptide (PACAP) and PACAP type I receptors in the rat adrenal medulla. Regul Pept 1996;63:129-139.
17 Nandha KA, Benito-Orfila MA, Smith DM, Ghatei MA, Bloom SR: Action of pituitary adenylate cyclase-activating polypeptide and vasoactive intestinal polypeptide on the rat vascular system: effects on blood pressure and receptor binding. J Endocrinol 1991;129: 69-73.

18 Ross-Ascuitto NT, Ascuitto RJ, Ramage D, Kydon DW, Coy DH, Kadowitz PJ: Pituitary adenylate cyclase activating polypeptide: a neuropeptide with potent inotropic and coronary vasodilatory effects in neonatal pig hearts. Pediatr Res 1993;34:323-328.

19 Ishizuka Y, Kashimoto K, Mochizuki T, Sato K, Ohshima K, Yanaihara N: Cardiovascular and respiratory actions of pituitary adenylate cyclase-activating polypeptides. Regul Pept 1992;40:29-39.

20 Markovics A, Kormos V, Gaszner B, Lashgarara A, Szoke E, Sandor K, Szabadfi K, Tuka B, Tajti J, Szolcsanyi J, Pinter E, Hashimoto H, Kun J, Reglodi D, Helyes Z: Pituitary adenylate cyclase-activating polypeptide plays a key role in nitroglycerol-induced trigeminovascular activation in mice. Neurobiol Dis 2012; 45:633-644.

21 Anzai M, Suzuki Y, Takayasu M, Kajita Y, Mori Y, Seki Y, Saito K, Shibuya M: Vasorelaxant effect of PACAP-27 on canine cerebral arteries and rat intracerebral arterioles. Eur J Pharmacol 1995;285:173-179.

22 Erdling A, Sheykhzade M, Maddahi A, Bari F, Edvinsson L: VIP/PACAP receptors in cerebral arteries of rat: characterization, localization and relation to intracellular calcium. Neuropeptides 2013;47:85-92.

23 Vamos Z, Ivic I, Cseplo P, Toth G, Tamas A, Reglodi D, Koller A: Pituitary adenylate cyclase-activating polypeptide (PACAP) induces relaxations of peripheral and cerebral arteries, which are differentially impaired by aging. J Mol Neurosci 2014;54:535-542.
12

J Vasc Res

DOI: $10.1159 / 000457798$
Ivic/Fulop/Juhasz/Reglodi/Toth/

Hashimoto/Tamas/Koller 
24 Cheng DY, McMahon TJ, Dewitt BJ, Carroll GC, Lee SS, Murphy WA, Bitar KG, Coy DH, Kadowitz PJ: Comparison of responses to pituitary adenylate cyclase activating peptides 38 and 27 in the pulmonary vascular bed of the cat. Eur J Pharmacol 1993;243:79-82.

25 Wilson AJ, Warren JB: Adenylate cyclase-mediated vascular responses of rabbit aorta, mesenteric artery and skin microcirculation. $\mathrm{Br} \mathrm{J}$ Pharmacol 1993;110:633-638.

26 Wallengren J: Vasoactive peptides in the skin. J Investig Dermatol Symp Proc 1997;2:49-55.

27 Miyata A, Sato K, Hino J, Tamakawa H, Matsuo $\mathrm{H}$, Kangawa K: Rat aortic smooth-muscle cell proliferation is bidirectionally regulated in a cell cycle-dependent manner via PACAP/ VIP type 2 receptor. Ann NY Acad Sci 1998; 865:73-81.

28 Cardell LO, Uddman R, Luts A, Sundler F: Pituitary adenylate cyclase activating peptide (PACAP) in guinea-pig lung: distribution and dilatory effects. Regul Pept 1991;36:379-390.

29 Harmar AJ, Sheward WJ, Morrison CF, Waser B, Gugger M, Reubi JC: Distribution of the VPAC2 receptor in peripheral tissues of the mouse. Endocrinology 2004;145:1203-1210.

30 Fahrenkrug J, Hannibal J, Tams J, Georg B: Immunohistochemical localization of the VIP1 receptor $\left(\mathrm{VPAC}_{1} \mathrm{R}\right)$ in rat cerebral blood vessels: relation to PACAP and VIP containing nerves. J Cereb Blood Flow Metab 2000;20:1205-1214.

31 Reglodi D, Kiss P, Szabadfi K, Atlasz T, Gabriel R, Horvath G, Szakaly P, Sandor B, Lubics A, Laszlo E, Farkas J, Matkovits A, Brubel R, Hashimoto H, Ferencz A, Vincze A, Helyes Z, Welke L, Lakatos A, Tamas A: PACAP is an endogenous protective factor - insights from PACAP-deficient mice. J Mol Neurosci 2012; 48:482-492.

32 Mori H, Nakamachi T, Ohtaki H, Yofu S, Sato A, Endo K, Iso Y, Suzuki H, Takeyama Y, Shintani N, Hashimoto H, Baba A, Shioda S: Cardioprotective effect of endogenous pituitary adenylate cyclase-activating polypeptide on doxorubicin-induced cardiomyopathy in mice. Circ J 2010;74:1183-1190.
33 Hashimoto H, Shintani N, Tanaka K, Mori W, Hirose M, Matsuda T, Sakaue M, Miyazaki J, Niwa H, Tashiro F, Yamamoto K, Koga K, Tomimoto S, Kunugi A, Suetake S, Baba A: Altered psychomotor behaviors in mice lacking pituitary adenylate cyclase-activating polypeptide (PACAP). Proc Natl Acad Sci USA 2001;98:13355-13360.

34 Józsa R, Hollósy T, Tamas A, Tóth G, Lengvári I, Reglodi D: Pituitary adenylate cyclase activating polypeptide plays a role in olfactory memory formation in chicken. Peptides 2005; 26:2344-2350.

35 Mulvany MJ, Halpern W: Contractile properties of small arterial resistance vessels in spontaneously hypertensive and normotensive rats. Circ Res 1977;41:19-26.

36 Ivic I, Vamos Z, Cseplo P, Koller A: From newborn to senescence morphological and functional remodeling leads to increased contractile capacity of arteries. J Gerontol A Biol Sci Med Sci 2016, Epubar of print.

37 Tamas A, Reglodi D, Farkas O, Kovesdi E, Pal J, Povlishock JT, Schwarcz A, Czeiter E, Szanto Z, Doczi T, Buki A, Bukovics P: Effect of $P A C A P$ in central and peripheral nerve injuries. Int J Mol Sci 2012;13:8430-8448.

38 Huang M, Shirahase H, Rorstad OP: Comparative study of vascular relaxation and receptor binding by PACAP and VIP. Peptides 1993. 14:755-762.

39 Syed AU, Koide M, Braas KM, May V, Wellman GC: Pituitary adenylate cyclase-activating polypeptide (PACAP) potently dilates middle meningeal arteries: implications for migraine. J Mol Neurosci 2012;48:574-583.

40 Chan KY, Baun M, de Vries R, van den Bogaerdt AJ, Dirven CM, Danser AH, JansenOlesen I, Olesen J, Villalón CM, MaassenVanDenBrink A, Gupta S: Pharmacological characterization of VIP and PACAP receptors in the human meningeal and coronary artery. Cephalalgia 2011;31:181-189.

41 Knutsson M, Edvinsson L: Distribution of mRNA for VIP and PACAP receptors in human cerebral arteries and cranial ganglia. Neuroreport 2002;13:507-509.

42 Otto C, Hein L, Brede M, Jahns R, Engelhardt S, Gröne HJ, Schütz G: Pulmonary hypertension and right heart failure in pituitary adenylate cyclase-activating polypeptide type I receptor-deficient mice. Circulation 2004; 110:3245-3251.
43 DiCicco-Bloom E, Deutsch PJ, Maltzman J, Zhang J, Pintar JE, Zheng J, Friedman WF, Zhou X, Zaremba T: Autocrine expression and ontogenetic functions of the PACAP ligand/receptor system during sympathetic development. Dev Biol 2000;219:197-213.

44 Waschek JA, Lelievre V, Bravo DT, Nguyen T, Muller JM: Retinoic acid regulation of the VIP and PACAP autocrine ligand and receptor system in human neuroblastoma cell lines. Peptides 1997; 18:835-841.

45 Hoover DB, Tompkins JD, Parsons RL: Differential activation of guinea pig intrinsic cardiac neurons by the PAC1 agonists maxadilan and pituitary adenylate cyclase-activating polypeptide 27 (PACAP27). J Pharmacol Exp Ther 2009;331:197-203.

46 Svensjö E, Saraiva EM, Amendola RS, BarjaFidalgo C, Bozza MT, Lerner EA, Teixeira MM, Scharfstein J: Maxadilan, the Lutzomyia longipalpis vasodilator, drives plasma leakage via PAC1-CXCR1/2-pathway. Microvasc Res 2012;83:185-193.

47 Karacay B, O’Dorisio MS, Kasow K, Hollenback C, Krahe R: Expression and fine mapping of murine vasoactive intestinal peptide receptor 1. J Mol Neurosci 2001;17:311-324.

48 Rodríguez-Martínez MA, García-Cohen EC, Baena AB, González R, Salaíces M, Marín J: Contractile responses elicited by hydrogen peroxide in aorta from normotensive and hypertensive rats: endothelial modulation and mechanism involved. Br J Pharmacol 1998; 125:1329-1335.

49 Miyata A, Arimura A, Dahl RR, Minamino N, Uehara A, Jiang L, Culler MD, Coy DH: Isolation of a novel 38 residue-hypothalamic polypeptide which stimulates adenylate cyclase in pituitary cells. Biochem Biophys Res Commun 1989;164:567-574.

50 Koide M, Syed AU, Braas KM, May V, Wellman GC: Pituitary adenylate cyclase activating polypeptide (PACAP) dilates cerebellar arteries through activation of large-conductance $\mathrm{Ca}^{2+}$-activated (BK) and ATP-sensitive $\left(\mathrm{K}_{\mathrm{ATP}}\right) \mathrm{K}^{+}$channels. J Mol Neurosci 2014;54: 443-450.
Vasomotor Backup Mechanisms in

PACAP Pathways
J Vasc Res

DOI: $10.1159 / 000457798$ 